\title{
Effect of in ovo and post-hatch administration of honey on the immunity and intestinal microflora of growing chickens
}

\author{
S.S. Memon ${ }^{1}$, A.A. Kamboh ${ }^{1,4}$, I.H. Leghari ${ }^{2}$ and R.A. Leghari ${ }^{3}$ \\ Sindh Agriculture University, Faculty of Animal Husbandry \& Veterinary Sciences \\ ${ }^{1}$ Department of Veterinary Microbiology, ${ }^{2}$ Department of Poultry Husbandry, ${ }^{3}$ Department of Veterinary Medicine \\ 70060 Tandojam, Pakistan
}

KEY WORDS: broilers, honey, immunity, in ovo, microbial flora, post-hatch

$\begin{array}{lrl}\text { Received: } & 27 \text { March } 2019 \\ \text { Revised: } & 18 \text { August } 2019\end{array}$

Accepted: 29 November 2019

${ }^{4}$ Corresponding author:

e-mail: drasgharkamboh@yahoo.com

\begin{abstract}
The present study evaluated the effect of honey administration in pre- and post-hatch sessions on the immunity and intestinal microflora of growing broilers. The pre-hatch experiment was conducted on fertile eggs $(n=160)$ that were inoculated either with $0.5 \mathrm{ml} 20 \%$ diluted honey (+pre-hatch) or with the same quantity of normal saline (-pre-hatch) on day 15 of incubation. After hatching, the chicks from each group were divided into two groups: control (-post-hatch) and the other receiving 1\% honey (+post-hatch) in drinking water up to day 21. The experimental groups: $\mathrm{C}=-$ pre-hatch/post-hatch, T1 = -pre-hatch/+post-hatch, T2 = +pre-hatch/-post-hatch and $\mathrm{T} 3=$ +pre-hatch/+post-hatch, were evaluated for performance parameters, antibody titer against Newcastle disease virus (NDV), relative weight of lymphoid organs and counts of gut microflora. It was shown that the pre-hatch honey administration significantly $(P<0.05)$ improved feed intake, final body weight, relative weight of spleen and anti-NDV antibody titer. Post-hatch honey supplementation significantly $(P<0.05)$ increased feed intake, FCR, final body weight, anti-NDV titer, relative weight of spleen and Lactobacilli count, while decreased $(P<0.05)$ the counts of Escherichia coli and Salmonella on day 21. The interaction of both the pre- and post-hatch honey administrations also significantly affected $(P<0.05)$ performance and immunity parameters, as well as the intestinal microflora. So, in ovo and post-hatch administration of honey had positive impacts on performance, immune organ indices, gut microbiota and anti-NDV titer in growing broiler chickens.
\end{abstract}

\section{Introduction}

Infectious diseases, particularly enteric diseases, constitute a major problem for commercial poultry farmers mainly because of the associated production losses, increased mortality rates and subsequent contamination of poultry products intended for human consumption. Therefore, the manipulation of gut microbiota and immunity of poultry chickens using feed additives has been known as an important strategy for improving the growth performance and reducing losses caused by diseases (Kamboh et al., 2016). In addition, a growing concern related to anti-microbial resistance of pathogens isolated from humans and food animals, together with the ban of the use of antibiotics as feed additives, have enhanced the focus of research on natural alternatives for the production of food animals (Raheema et al., 2016).

In ovo feeding refers to an administration of exogenous nutrients into avian fertile eggs in the form of a solution. Some natural substances can also be used for exogenous administration into fertile eggs. 
The developmental environment of the chicken embryo has a limited amount of in ovo energy and nutrients (Ferket and Uni, 2002; Foye et al., 2006). These natural substances can modify enteric development to improve the hatchling's status during the transition from embryonic nutrition to diet digestive competence. In addition, in recent studies the importance of in ovo feeding of nutritional and non-nutritional compounds to enhance cellular, humoral and mucosal immunity was also highlighted (Kadam et al., 2013). During development, appropriate nutrition may minimize the incidence of disease by increasing the availability of certain nutrients, which can modulate the function of the immune system through various mechanisms (Korver and Klasing, 2001) and so enhance immunity (Batool et al., 2002). The functional properties of some natural products, such as herbal extracts (Chang et al., 2007; Ali et al., 2016), probiotics (Nichols, 2007), prebiotics (Ahossi et al., 2016) and enzymes (Eisenthal and Danson, 2002), augment the immunity in the animal model systems. Hence, there is an increasing trend for using natural compounds as feed additives in animal production.

Honey, a sweet and viscous natural food product formed from the nectar of flowers by honeybees (Alvarez-Suarez et al., 2014), is an important insectderived natural product that has proven therapeutic, spiritual, traditional and cosmetic importance throughout the human history. It contains, \%: fructose 38.2 , glucose 31.3 , maltose 7.1, sucrose 1.3, other sugars 1.5, ash 0.2 and water 17.2. It also contains trace amounts of proteins, dietary fibres, vitamins and minerals (USDA, 2014). It has shown many biological activities, such as anti-inflammatory, antioxidant, antimicrobial and immunostimulatory effects (Alvarez-Suarez et al., 2014), which are mainly accredited to its chemical composition including polyphenols, flavonoids, diterpene acids and aromatic compounds (Lofty et al., 2006).

Till now, the research related to the effects of honey as a feed additive for poultry, particularly its effects on embryonic development and growth, is quite limited. Therefore, in the present study in ovo and supplemental effects of honey during post-hatch life on the immunity and gut microflora of growing broiler chickens were investigated.

\section{Material and methods}

\section{Pre-hatch treatment}

All the experimental procedures were approved by the Board of Advanced Studies, Sindh Agriculture University, Tandojam (Pakistan). Fertile Hubbard breeder eggs, $(\mathrm{n}=160 ; 46-52 \mathrm{~g})$ of 34 weeks age, were purchased from a commercial hatchery, and brought to the Poultry Experimental Station, Department of Poultry Husbandry, Faculty of Animal Husbandry and Veterinary Sciences, SAU (Tandojam, Pakistan). The eggs were initially fumigated, candled, weighed, and randomly divided into 2 groups. The eggs were inoculated either with $0.5 \mathrm{ml}$ of $20 \%$ diluted honey (Marhaba Laboratories, Lahore, Pakistan) (+prehatch) or with the same quantity of normal saline (-pre-hatch) through injection in the yolk sac and sealed with molten paraffin on day 15 of the incubation. For in ovo injection honey dose was adopted from a recent study (Abdullah et al., 2018). All the eggs were incubated according to standard hatchery practices $\left(37.72\right.$ to $37.78{ }^{\circ} \mathrm{C} ; 60$ to $70 \%$ humidity) up to day 21.

\section{Post-hatch treatment and farming condition}

At the first day post-hatch, the chicks from both groups were further divided into two groups (five replicates per group), one served as control (-post-hatch), while the other was given 1\% honey (+post-hatch) in drinking water up to day 21 . The dosage of honey was adopted based on our preliminary trails that used different dosages keeping in view the feasible cost of honey (unpublished data). The chicks of all the four experimental groups $(\mathrm{C}=-$ pre-hatch/-post-hatch, $\mathrm{T} 1=-$ pre-hatch $/+$ posthatch, $\mathrm{T} 2=+$ pre-hatch $/-$ post-hatch and $\mathrm{T} 3=+$ prehatch/+post-hatch) were initially weighed and transferred into an experimental house for subsequent evaluation of growth performance. A floor space of $464 \mathrm{~cm}^{2}$ per broiler was provided during the brooding period, and $929 \mathrm{~cm}^{2}$ per broiler during the later stage of rearing. The chicks were reared for three weeks of age, and supplied with a standard broiler feed, which was formulated considering the nutritional requirements of broilers during the starter period (days 1-21 of age) according to National Research Council (NRC, 1994) recommendations (Table 1). The temperature was maintained at $35^{\circ} \mathrm{C}$ during the $1^{\text {st }}$ week, $32.2{ }^{\circ} \mathrm{C}$ during the $2^{\text {nd }}$ week and $29.4{ }^{\circ} \mathrm{C}$ during the $3^{\text {rd }}$ week. Feed and water were provided ad libitum. All chicks were vaccinated with Newcastle disease virus (NDV, $B_{1}$ strain vaccine) on the day 5 of age. Feed consumption and body weight gain (BWG) were recorded, and used to calculate the feed conversion ratio (FCR).

\section{Sample collection and analysis}

At day 21 of age, five birds from each group (one per replicate) were randomly chosen, weighed and slaughtered. The weights of lymphoid organs 
Table 1. Ingredients and chemical composition of feed

\begin{tabular}{|c|c|}
\hline Indices & $\%$ \\
\hline \multicolumn{2}{|l|}{ Ingredients } \\
\hline yellow maize & 52 \\
\hline soyabean meal, $30 \% \mathrm{CP}$ & 29 \\
\hline maize gluten, $60 \% \mathrm{CP}$ & 7.00 \\
\hline vegetable oil & 4.00 \\
\hline wheat bran & 3.43 \\
\hline bone meal & 3.30 \\
\hline lime stone & 0.14 \\
\hline premix $^{1}$ & 0.30 \\
\hline $\mathrm{NaCl}$ (salt) & 0.50 \\
\hline L-lysine-HCL & 0.18 \\
\hline DL-methionine & 0.15 \\
\hline \multicolumn{2}{|l|}{ Analysed chemical composition } \\
\hline metabolizing energy, kcal/kg & 3100 \\
\hline dry matter & 89.07 \\
\hline crude protein $(\mathrm{CP})$ & 23.07 \\
\hline ether extract & 6.50 \\
\hline crude fibre & 3.80 \\
\hline lysine & 1.22 \\
\hline methionine & 0.56 \\
\hline calcium & 0.92 \\
\hline methionine+cysteine & 0.92 \\
\hline available $P, \%$ & 0.48 \\
\hline
\end{tabular}

${ }^{1}$ premix: IU: vit. A 12000; mg: vit. E 10, vit. K 2, vit. B1 1, vit. B2 5 , vit. B6 1.5, vit. B12 10, nicotinic acid 30, folic acid 1, pantothenic acid 10, biotin 50, choline chloride 500, Cu 10, Fe 30, Mg 60, Zn 50, I 1, Se 0.1, Co 0.1

(spleen, thymus and bursa of Fabricius) were measured using a digital weighing balance, while the relative weight of lymphoid organs was calculated. The caecal contents (about $10 \mathrm{~g}$ ) were collected aseptically into sterile Eppendorf tubes, and stored at $-4{ }^{\circ} \mathrm{C}$ to enumerate the caecal microflora. Blood samples $(5 \mathrm{ml})$ were collected on days 15 and 21 from the wing vein using sterile syringes, and allowed to clot for $30 \mathrm{~min}$ at room temperature for the collection of sera, which were analysed for anti-NDV antibody titers using the standard method of Majiyagbe and Hitchner (1977). The endpoint of each serum sample was determined using haemagglutination inhibition method, while the results were calculated as $\log _{2}$ of the reciprocal of the last dilution.

The caecal contents were enumerated for the determination of total bacterial count, as well as counts of Escherichia coli, Salmonella and Lactobacilli following the procedure of Sultan et al. (2015). The samples were weighed ( $1 \mathrm{~g})$ and serially diluted (ten-fold) in $0.9 \%$ saline and vortexed. Approximately, $1 \mathrm{ml}$ of each sample was dispensed and spread on general and selective media in the petri dishes including, MacConkey agar for E. coli count, Brilliant Green agar for Salmonella and
de-Man-Rogosa Sharpe (MRS) agar plates for total Lactobacilli. All the media were prepared according to the manufacturer's instructions (Oxoid, Basingstoke, UK). The microbial suspensions from each dilution of the samples were transferred through the pour plate method (Quinn et al., 1992) and incubated at $37{ }^{\circ} \mathrm{C}$ for $24 \mathrm{~h}$. The pathogens were identified by growing on specific media and biochemical tests. Subsequently, the colonies were counted using a colony counter, while the results were expressed as $\mathrm{CFU} / \mathrm{g}$ of the contents.

\section{Statistical analysis}

The collected data were tabulated and analysed by using the analysis of variance (ANOVA) followed by Tukey's post-hoc test through JMP statistical package software (version 5.0.1.a, SAS Institute Inc., Cary, NC, USA) as $2 \times 2$ factorial arrangements with pre- (in ovo) and post-hatch honey treatments as the main effects. Level of significance was determined at $P<0.05$. All the results were presented as mean and standard error (mean $\pm \mathrm{SE}$ ).

\section{Results}

\section{Effect on honey treatment on performance}

Feed intake was the highest in -pre-hatch/+posthatch (T1) followed by + pre-hatch/+post-hatch (T3), +pre-hatch/-post-hatch (T2) and control (C) groups (Table 2). Statistical analysis revealed that both the pre- and post-hatch honey treatments improved $(P<0.05)$ the feed intake. In addition, the interaction of both the pre- and post-hatch honey treatments was also significant.

Similarly, both pre- and post-hatch honey treatments improved the body weight gain (BWG) of the growing broilers (Table 2) and also their interaction was significant. The highest BWG (g/bird) was recorded in T1 group, while the lowest value was observed in group $\mathrm{C}$.

The best feed conversion ratio (FCR) was recorded in $\mathrm{T} 1$, followed by $\mathrm{T} 2, \mathrm{~T} 3$ and $\mathrm{C}$ groups, respectively. Statistical analysis showed that the posthatch treatment significantly decreased $(P<0.05)$ the FCR, while the pre-hatch treatment did not exhibit any effect $(P>0.05)$ on FCR. Moreover, the interaction of the pre- and post-hatch honey treatments was also significant.

\section{Effect of honey treatment on anti-NDV antibody titer}

The $\mathrm{T} 1$ group exhibited the highest rise in antiNDV antibody titer on day 15 , followed by T2, 
Table 2. Effect of in ovo and post-hatch administrations of honey on performance of growing broilers

\begin{tabular}{|c|c|c|c|c|c|c|c|}
\hline \multirow{2}{*}{ Indices } & \multicolumn{4}{|l|}{ Groups $^{1}$} & \multicolumn{3}{|l|}{$P$-value } \\
\hline & $\mathrm{C}$ & $\mathrm{T} 1$ & $\mathrm{~T} 2$ & T3 & pre-hatch honey & post-hatch honey & interaction \\
\hline Feed intake, g & $1151 \pm 4.3^{\mathrm{d}}$ & $1199 \pm 3.4^{a}$ & $1156 \pm 7.5^{c}$ & $1162 \pm 6.1^{b}$ & 0.006 & 0.003 & 0.001 \\
\hline Body weight, g & $579.8 \pm 7.4^{c}$ & $708 \pm 4.8^{a}$ & $691.2 \pm 5.1^{b}$ & $685 \pm 11.9^{b}$ & $<0.001$ & $<0.001$ & $<0.001$ \\
\hline FCR, g/g & $1.74 \pm 0.01^{\mathrm{a}}$ & $1.41 \pm 0.03^{\mathrm{d}}$ & $1.54 \pm 0.03^{c}$ & $1.61 \pm 0.05^{b}$ & 0.901 & 0.001 & $<0.001$ \\
\hline
\end{tabular}

${ }^{1} \mathrm{C}$ : -pre hatch/-post hatch, T1: -pre hatch/+post hatch, T2: +pre hatch/-post hatch, T3: +pre hatch/+post hatch; ${ }^{\mathrm{a}-\mathrm{d}}-$ means with different superscripts within each row are significantly different according to two-way ANOVA with Tukey's post-hoc test at $P \leq 0.05$

$\mathrm{T} 3$ and $\mathrm{C}$ groups, however $\mathrm{T} 2$ and $\mathrm{T} 3$ groups did not differ (Figure 1A). Both pre- and post-hatch honey treatments improved $(P<0.05)$ the antibody titer. In addition, the interaction of the pre- and post-hatch honey treatments was also statistically significant.

Similarly, the post-hatch honey treatment and the interaction of the pre- and post-hatch honey treatments also significantly improved the antiNDV antibody titer on day 21; however, the prehatch honey treatment did not affect $(P>0.05)$ the antibody titer. The highest rise in the antibody titer was recorded in group T1, followed by T2, T3 and C groups (Figure 1B).

\section{Effect on honey treatment on the relative weight of immune organs}

The results of two-way ANOVA indicated that the overall effects of the pre- and post-hatch honey treatments on the bursa of Fabricius index, as well as their interaction, remained statistically non-significant (Table 3).
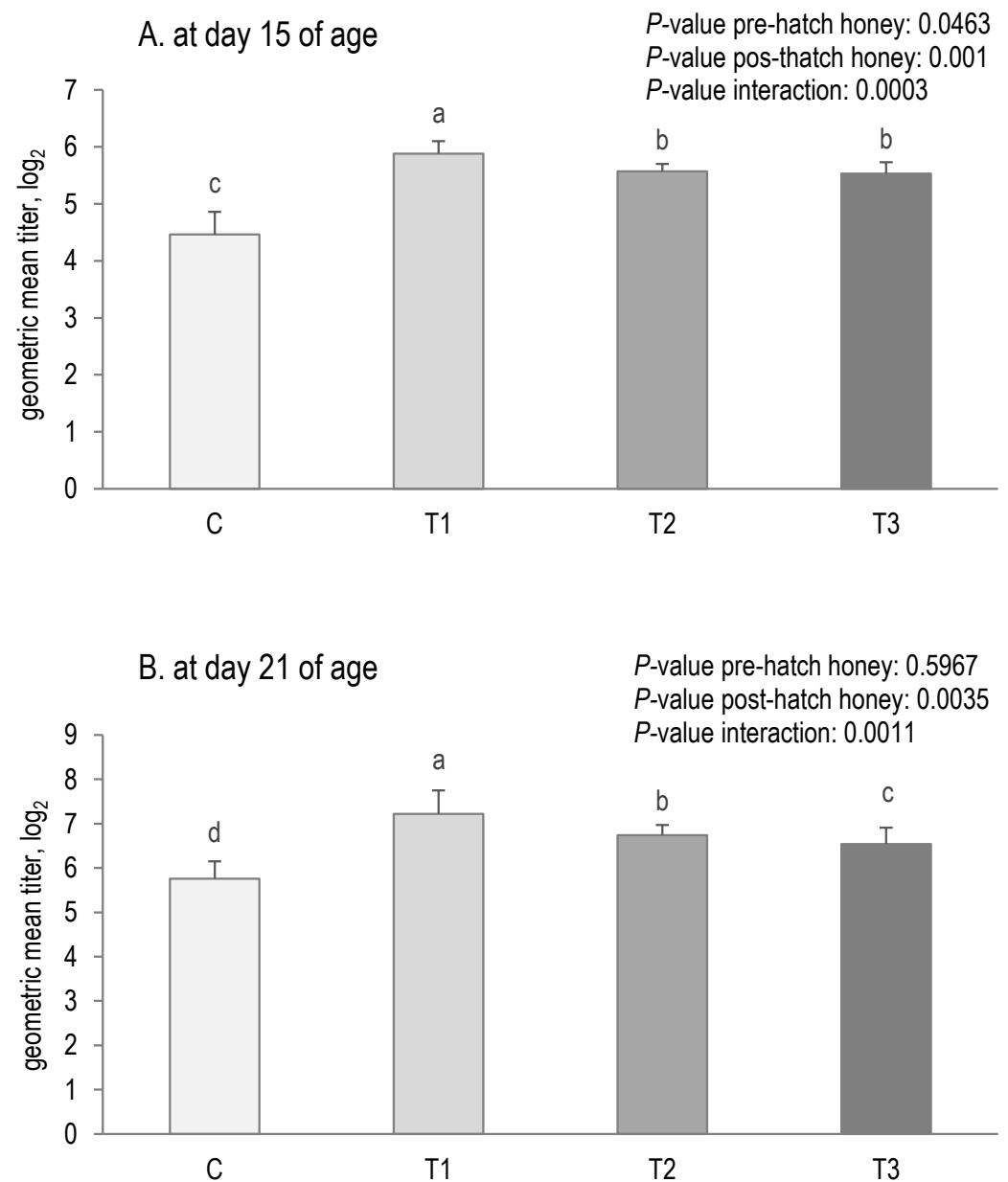

Figure 1. Effect of in ovo and post-hatch administrations of honey on serum anti-Newcastle disease virus (NDV) antibody titers (log 2 ) in growing broilers at day 15 of age $(A)$ and at day 21 of age (B)

Groups: C: -pre hatch/-post hatch, T1: -pre hatch/+post hatch, T2: +pre hatch/-post hatch, T3: +pre hatch/+post hatch; ${ }^{a-d}$ - bars with different superscripts are significantly different according to two-way ANOVA with Tukey's post-hoc test at $P \leq 0.05$ 
Table 3. Effect of in ovo and post-hatch administrations of honey on relative weight of immune organs in growing broilers, g/g

\begin{tabular}{|c|c|c|c|c|c|c|c|}
\hline \multirow[b]{2}{*}{ Indices } & \multicolumn{4}{|l|}{ Groups 1} & \multicolumn{3}{|l|}{$P$-value } \\
\hline & C & $\mathrm{T} 1$ & T2 & T3 & $\begin{array}{l}\text { pre-hatch } \\
\text { honey }\end{array}$ & $\begin{array}{l}\text { post-hatch } \\
\text { honey }\end{array}$ & interaction \\
\hline Bursa of Fabricius & $0.17 \pm 0.04$ & $0.21 \pm 0.03$ & $0.19 \pm 0.04$ & $0.20 \pm 0.09$ & 0.816 & 0.085 & 0.082 \\
\hline Thymus & $0.29 \pm 0.01^{b}$ & $0.42 \pm 0.03^{a}$ & $0.40 \pm 0.03^{\mathrm{a}}$ & $0.32 \pm 0.01^{b}$ & $<0.921$ & 0.463 & 0.007 \\
\hline Spleen & $0.10 \pm 0.01^{c}$ & $0.14 \pm 0.00^{\mathrm{a}}$ & $0.12 \pm 0.00^{b}$ & $0.15 \pm 0.01^{a}$ & 0.004 & 0.038 & 0.004 \\
\hline
\end{tabular}

${ }^{1} \mathrm{C}$ : -pre hatch/-post hatch, T1: -pre hatch/+post hatch, T2: +pre hatch/-post hatch, T3: +pre hatch/+post hatch; ${ }^{\mathrm{a}-\mathrm{c}}-$ means with different superscripts within each row are significantly different according to two-way ANOVA with Tukey's post-hoc test at $P \leq 0.05$

In addition, $\mathrm{T} 1$ and $\mathrm{T} 2$ groups exhibited higher relative weight of thymus in comparison to $\mathrm{T} 3$ and $\mathrm{C}$ ones. None of the pre- and post-hatch honey treatments showed any significant effect on the relative weight of thymus; however the interaction of the main effects was also statistically significant.

Moreover, T1, T2 and T3 groups had higher relative weight of spleen in comparison to $\mathrm{C}$ group. Both the pre- and post-hatch honey treatments significantly improved the spleen index. In addition, the interaction of the pre- and post-hatch honey treatment was also statistically significant. count was observed in T1, followed by T3 and T2, respectively. The effect of post-hatch honey treatment, as well as the interaction of pre- and post-hatch honey treatments were also significant. However, the effect of pre-hatch honey was non-significant $(P=0.05)$.

The T1 group showed the highest increase in Lactobacilli count, and the lowest value was observed in the $\mathrm{C}$ group. The effect of post-hatch honey treatment, as well as the interaction of pre- and posthatch honey treatments were significant. In contrast, the effect of pre-hatch treatment showed nonsignificant effects on Lactobacilli count in broilers.

Table 4. Effect of in ovo and post-hatch administrations of honey on caecal microflora of growing broilers, cfu/g

\begin{tabular}{|c|c|c|c|c|c|c|c|}
\hline \multirow[t]{2}{*}{ Indices } & \multicolumn{4}{|l|}{ Groups $^{1}$} & \multicolumn{3}{|l|}{$P$-value } \\
\hline & C & $\mathrm{T} 1$ & T2 & T3 & $\begin{array}{l}\text { pre-hatch } \\
\text { honey }\end{array}$ & $\begin{array}{l}\text { post-hatch } \\
\text { honey }\end{array}$ & interaction \\
\hline Total bacterial count & $1.50 \times 10^{5} \pm 0.05^{c}$ & $2.03 \times 10^{5} \pm 0.15^{b}$ & $2.13 \times 10^{5} \pm 0.17^{\mathrm{a}}$ & $1.53 \times 10^{5} \pm 0.10^{c}$ & 0.750 & 0.660 & 0.004 \\
\hline Escherichia coli count & $2.43 \times 10^{4} \pm 0.09^{a}$ & $1.54 \times 10^{4} \pm 0.09^{d}$ & $1.82 \times 10^{4} \pm 0.17^{c}$ & $1.90 \times 10^{4} \pm 0.07^{b}$ & 0.521 & 0.002 & 0.002 \\
\hline Salmonella count & $1.33 \times 10^{4} \pm 0.05^{a}$ & $0.38 \times 10^{4} \pm 0.07^{d}$ & $0.85 \times 10^{4} \pm 0.03^{b}$ & $0.60 \times 10^{4} \pm 0.07^{c}$ & 0.050 & $<0.001$ & $<0.001$ \\
\hline Lactobacilli count & $1.55 \times 10^{4} \pm 0.09^{d}$ & $2.17 \times 10^{4} \pm 0.08^{a}$ & $1.82 \times 10^{4} \pm 0.07^{c}$ & $1.90 \times 10^{4} \pm 0.08^{b}$ & 0.842 & 0.001 & 0.003 \\
\hline
\end{tabular}

${ }^{1} \mathrm{C}$ : -pre hatch/-post hatch, T1: -pre hatch/+post hatch, T2: +pre hatch/-post hatch, T3: +pre hatch/+post hatch; a-d - means with different superscripts within each row are significantly different according to two-way ANOVA with post-hoc Tukey's test at $P \leq 0.05$

\section{Effect on honey treatment on caecal microflora}

The effects of the pre- and post-hatch honey treatments on total bacteria count were non-significant (Table 4); however the interaction of main effects was statistically significant. The T2 group exhibited the highest count of total viable bacteria followed by $\mathrm{T} 1$, $\mathrm{T} 3$ and $\mathrm{C}$ groups; however T3 and C groups did not differ.

On the other hand, the E. coli count of caecal contents was the highest in the control group, followed by T3, T2 and T1 groups. Moreover, the effects of the post-hatch honey treatment, as well as the interaction of the pre- and post-hatch honey treatments were statistically significant. However, the pre-hatch treatment showed non-significant effects on the E. coli population.

Similar to E. coli, the highest count for Salmonella was also observed in $\mathrm{C}$ group, while the lowest

\section{Discussion}

In ovo supplementation of different compounds, such as glucose (Salmanzadeh, 2012), nano forms of zinc, copper and selenium (Joshua et al., 2016), royal jelly (Moghaddam et al., 2013), amino acids (Ohta et al., 2001) and carbohydrates (Zhai et al., 2011), has previously been examined by many researchers. However, to our knowledge, this is the first study in which honey was injected into broiler breeder eggs to investigate its effects on immunity and gut microflora during post-hatch life. Our results regarding improved feed intake and body weight of broilers during the starter period are consistent with the previous works of Shafey et al. (2014), Salmanzadeh, (2012) and Moghaddam et al. (2013), who reported improvements in weight gain, feed intake and FCR of chickens connected with the in ovo administration of amino acids, glucose and 
royal jelly. Honey sugars, in comparison to cane sugar, have beneficial effects on appetite-regulating hormones (Larson-Meyer et al., 2010). In addition, the supplementation of honey into drinking water has been used to improve the feed intake that directly correlates with the weight gain and FCR, particularly through improving the intestinal health and digestion, as well as by prevention of nutrients wastage from the gut (Hegazi et al., 2013). The results of the present study also coincide with the findings of Kornasio et al. (2011), who reported that in ovo feeding exogenous nutrients or post-hatch additives boosts the intestinal growth via improving villi size, which helps in the capacity of digestion, thus improves FCR. On the other hand, the results of Abioja et al. (2012) are in contrast with the present findings, who reported non-significant effects in the final body weight gain and feed intake among groups offered honey-supplemented water and control group.

In the current study, each bird from honey supplemented groups (T1 and T3) received an additional 100 calories energy by honey supplementation in the 21 -day period. As this energy $(100 \mathrm{cal})$ was shared during 21 days, the resultant was a very little amount of energy (only about $5 \mathrm{cal} /$ day). Hence it could be stated that honey as a mixture of saccharides has no effect on the performance (e.g., body weight) of broilers. On the other hand, honey contains a number of health enhancing and growth promoting agents like vitamins (including riboflavin, niacin, folic acid, pantothenic acid, ascorbic acid and vitamin B6), trace elements (like calcium, iron, zinc, potassium, phosphorous, magnesium, selenium, chromium and manganese) and antioxidant polyphenols (Ball, 2007; USDA, 2014). It has been estimated that each $\mathrm{g}$ of honey contains about $1 \mathrm{mg}$ of polyphenols with total antioxidant capacity of $296 \mathrm{mg}$ gallic acid equivalents (Islam et al., 2017). Hence, it is advisable to credit positive effects of honey supplementation observed in this study to noncarbohydrate constituents of honey.

In the present study, the increase of antibody titer in the honey-treated chickens, as compared to that of control, reflected the immunostimulatory action of honey. Orsi et al. (2000) stated that honey possesses immunomodulatory effects, as it influences the initiation of macrophages and antibody synthesis in vitro. In addition, Yuan et al. (2012) reported that honey contains flavonoid liposomes that may increase the antibody titer in a dose-dependent manner. Moreover, natural honey is a rich source of polyphenols, including flavonoids, flavonols and flavones (about $20 \mathrm{mg} / 100 \mathrm{~g}$ ), which possess antibacterial, antioxidative and immunomodulatory properties (Kimoto et al., 1999; Prytzyk et al., 2003).

The relative weights of lymphoid organs (spleen, thymus, and bursa of Fabricius) were assessed in this study as the direct indices of immunestimulation. Honey administration improved the indices for all the lymphoid organs, with pronounced effects on the spleen index. A similar observation was reported by Orsi et al. (2000), who stated that honey influenced the weight of lymphoid organs via activation of macrophages antibody synthesis. On the other hand, Hegazi et al. (2013) reported a nonsignificant observation but numerically improved the weight of lymphoid organs in honey treated chickens, as compared to that of the control group. The authors further resolved that the increase in the weight of lymphoid organs was due to the high production of T cells via activation of mitosis. Furthermore, the results of the present study coincide with the findings of Abioja et al. (2012), who concluded that supplementation of $20 \mathrm{ml}$ honey per 1 of drinking water increased the weight of thymus.

In the current study, honey administration during post-hatch session improved the Lactobacilli count in the treated broilers, as compared to those of the control group. Hajati et al. (2014) reported that Lactobacilli suppress undesirable enteric microorganisms like E. coli; maintain intestinal immune homeostasis, prevent inflammation and release bactericidal or bacteriostatic chemicals. In addition, Landry et al. (2016) reviewed that honey is an exceptional source of prebiotic oligosaccharides, like fructo-oligosaccharide, galacto-oligosaccharide, and it enhances the viability of probiotic lactic acid bacteria. Prebiotics are the substances, which cannot be digested by pathogenic microorganisms, and thereby selectively enhance the development of probiotics, hence confer health-benefits through the production of various metabolites, as well as by reduction of pathogenic microorganisms through competition (Deraz, 2018). Overall, these findings support the present results regarding the improvement of growth performance and immunomodulatory observations in this study.

Feeding probiotics in post-hatch period helps to maintain a beneficial intestinal microflora, augments the host's immune system, and results in a healthy gastrointestinal environment with an enhanced gut function and feed conversion that results in improved weight gain and performance of birds (Vilà et al., 2009; Mountzouris et al., 2010). Whereas, in ovo administration of probiotics is known to 
improve early performance and immunity against coccidiosis in broilers (Pender et al., 2016). In addition, prebiotics are non-digestible feed ingredients that beneficially affect the host by selective stimulation of the growth and activity of one or a limited number of bacteria (Patterson and Burkholder, 2003). In ovo administration of probiotics is also observed as beneficial in improving the digestive potency and weight gain, (Pruszynska-Oszmalek et al., 2015) and development of lymphoid organs (Madej et al., 2015) in broilers. In the present study, Lactobacilli counts were higher in the control group, which might be a reason of lower counts of E. coli and Salmonella. Similar observation was made by Hajati et al. (2014), who reported the reduction in the growth of undesirable intestinal microflora like $E$. coli by higher numbers of Lactobacilli. In another study, Tannock et al. (1974) noted that the gut microflora provided a natural barrier against the harmful bacteria, which subsequently prevented the growth of exogenous and pathogenic bacteria, as well as produced bacteriocins and other substances that augmented the immune system, thus increased the helpful microorganisms in the intestine. Hence, in the present study, the in ovo administration of honey acted as a prebiotic that served as feed for the endogenous probiotics, hence suppressed the growth of exogenous pathogenic microbes.

In the current study, honey played a role of an immunostimulatory and endogenous microflora modulatory agent that might lead to better performance of broilers. In previous studies it was shown that in honey can be found several types of biologically active agents including flavonoids that have been attributed as best immunomodulatory, gut modulatory and microflora adjusting agents in poultry (Kamboh et al., 2015; 2018). However, the flavonoids extracted from honey should be screened for their biological potential and be compared with those extracted from botanicals.

\section{Conclusions}

In ovo and post-hatch administration of honey had a positive impact on performance, immune organ indices and anti-Newcastle disease virus antibody titer in growing broilers. Moreover, honey administration positively influenced the population of gut microbiota in growing animals. Nonetheless, further studies are needed to examine the effect of different doses of honey on gut microbiota and immunity in immunologically challenged broilers. The obtained results will allow to draw a comprehensive conclusion regarding the immunomodulatory potential of honey and its possible inclusion into broiler diets.

\section{References}

Abdullah S., Leghari I.H., Moriani A.A., Rajput N., Gandahi J., Nisa M., 2018. Effect of in ovo supplementation of honey in fertile eggs on post hatch growth performance of broiler chickens. J. Anim. Plant Sci. 28, 1584-1590

Abioja M.O., Ogundimu K.B., Akibo T.E., Odukoya K.E., Ajiboye O.O., Abiona J.A., Williams T.J., Oke E.O., Osinowo O.A., 2012. Growth, mineral deposition, and physiological responses of broiler chickens offered honey in drinking water during hotdry season. Int. J. Zool. 2012, article ID 403502, http://dx.doi. org/10.1155/2012/403502

Ahossi P.K., Dougnon J.T., Kiki P.S., Houessionon J.M., 2016. Effects of Tridax procumbens powder on zootechnical, biochemical parameters and carcass characteristics of Hubbard broiler chicken. J. Anim. Health Prod. 4, 15-21, https://doi. org/10.14737/journal.jahp/2016/4.1.15.21

Ali A.H., Abdul-Azeez L.A., Humood J.K., Ali Z.A., Helal Z.H., Wahab F.L., 2016. The effect of ethanolic extract of Hibiscus sabdariffa on some physiological and antioxidant parameters in female rabbits. J. Anim. Health Prod. 4, 37-41, https://doi. org/10.14737/journal.jahp/2016/4.2.37.41

Alvarez-Suarez J.M., Gasparrini M., Forbes-Hernández T.Y., Mazzoni L., Giampieri F., 2014. The composition and biological activity of honey: a focus on Manuka honey. Foods 3, 420-432, https:// doi.org/10.3390/foods 3030420

Ball D.W., 2007. The chemical composition of honey. J. Chem. Educ. 84, 1643, https://doi.org/10.1021/ed084p1643

Batool A., Akhtar S., Rehman A.A., 2002. Effect of different plans of nutrition on immune response against Newcastle disease in cross (FAY $\times$ RIR) chicken. J. Biol. Sci. 2, 214-216, https://doi. org/10.3923/jbs.2002.214.216

Chang H.-F., Lin Y.-H., Chu C.-C., Wu S.-J., Tsai Y.-H., Chao J.C.-J., 2007. Protective effects of Ginkgo biloba, Panax ginseng and Schizandra chinensis extract on liver injury in rats. Am. J. Chin. Med. 35, 995-1009, https://doi.org/10.1142/ S0192415X07005466

Deraz S.F., 2018. Synergetic effects of multispecies probiotic supplementation on certain blood parameters and serum biochemical profile of broiler chickens. J. Anim. Health Prod. 6, 27-34, https://doi.org/10.17582/journal.jahp/2018/6.1.27.34

Eisenthal R., Danson M.J. (Editors), 2002. Enzyme Assays. $2^{\text {nd }}$ Edition. Oxford University Press. Oxford (UK)

Ferket P.R., Uni Z., 2002. Early enteric development of turkeys. In: Proceedings of the $25^{\text {th }}$ Technical Turkey Conference. 24-26.04.2002. Macclesfield (UK), pp. 59-64

Foye O.T., Uni Z., Ferket P.R., 2006. Effect of in ovo feeding egg white protein, $\beta$-hydroxy- $\beta$-ethylbutyrate, and carbohydrates on glycogen status and neonatal growth of turkeys. Poult. Sci. 85, 1185-1192, https://doi.org/10.1093/ps/85.7.1185

Hajati H., Hassanabadi A., Golian A., Nassiri-Moghaddam H., Nassiri M., 2014. The effect of in ovo injection of grape seed extract and vitamin $C$ on hatchability, antioxidant activity, yolk sac absorption, performance and ileal micro flora of broiler chickens. Res. Opin. Anim. Vet. Sci. 4, 633-638

Hegazi A., Abdou A.M., Abd Allah F., 2013. Influence of honey on immune response against Newcastle Disease vaccine. Int. J. Basic App. Virol. 2, 1-5, https://doi.org/10.5829/idosi.ijbav.2013.2.1.8154

Islam M.R., Pervin T., Hossain H., Saha B., Hossain S.J., 2017. Physicochemical and antioxidant properties of honeys from the Sundarbans mangrove forest of Bangladesh. Prev. Nutr. Food Sci. 22, 335-344, https://doi.org/10.3746/pnf.2017.22.4.335 
Joshua P.P., Valli C., Balakrishnan V., 2016. Effect of in ovo supplementation of nano forms of zinc, copper, and selenium on post-hatch performance of broiler chicks. Vet. World 9, 287294, https://doi.org/10.14202/vetworld.2016.287-294

Kadam M.M., Barekatain M.R., Bhanja K.S., lji P.A., 2013. Prospects of in ovo feeding and nutrient supplementation for poultry: the science and commercial applications - a review. J. Sci. Food Agric. 93, 3654-3661, https://doi.org/10.1002/jsfa.6301

Kamboh A.A., Memon A.M., Mughal M.J., Memon J., Bakhetgul M., 2018. Dietary effects of soy and citrus flavonoid on antioxidation and microbial quality of meat in broilers. J. Anim. Physiol. Anim. Nutr. 102, 235-240, https://doi.org/10.1111/jpn.12683

Kamboh A.A., Arain M.A., Mughal M.J., Zaman A., Arain Z.M., Soomro A.H., 2015. Flavonoids: health promoting phytochemicals for animal production - a review. J. Anim. Health Prod. 3, 6-13, https://doi.org/10.14737/journal.jahp/2015/3.1.6.13

Kamboh A.A., Hang S.-Q., Khan M.A., Zhu W.-Y., 2016. In vivo immunomodulatory effects of plant flavonoids in lipopolysaccharide-challenged broilers. Animal 10, 1619-1625, https://doi. org/10.1017/S1751731116000562

Kimoto N., Hirose M., Kawabe M., Satoh T., Miyataka H., Shirai T., 1999. Post-initiation effects of a super critical extract of propolis in a rat two-stage carcinogenesis model in female F344 rats. Cancer Lett. 147, 221-227, https://doi.org/10.1016/ S0304-3835(99)00305-5

Kornasio R., Halevy O., Kedar O., Uni Z., 2011. Effect of in ovo feeding and its interaction with timing of first feed on glycogen reserves, muscle growth, and body weight. Poult. Sci. 90, 1467-1477, https://doi.org/10.3382/ps.2010-01080

Korver D., Klasing K., 2001. Influence of nutrition on immune status of the bird. In: Proceedings of the $24^{\text {th }}$ Technical Turkey Conference. 26-27.04.2001. Leyburn (UK), p. 43

Landry B.K.U., Moumita S., Jayabalan R., François Z.N., 2016. Honey probiotic and prebiotic, a review. Res. J. Pharm. Biol. Chem. Sci. 7, 2428-2438

Larson-Meyer D.E., Willis K.S., Willis L.M., Austin K.J., Hart A.M., Breton A.B., Alexander B.M., 2010. Effect of honey versus sucrose on appetite, appetite-regulating hormones, and postmeal thermogenesis. J. Am. Coll. Nutr. 29, 482-493, https:// doi.org/10.1080/07315724.2010.10719885

Lofty M., 2006. Biological activity of bee propolis in health and disease. Asian Pac. J. Cancer Prev. 7, 22-31

Madej J.P., Stefaniak T., Bednarczyk M., 2015. Effect of in ovo-delivered prebiotics and synbiotics on lymphoid-organs' morphology in chickens. Poult. Sci. 94, 1209-1219, https://doi. org/10.3382/ps/pev076

Majiyagbe K.A., Hitchner S.B., 1977. Antibody response to strain combination of Newcastle Disease Virus as measured by hemagglutination-inhibition. Avian Dis. 21, 576-584, https:// doi.org/10.2307/1589416

Moghaddam A., Karimi I., Borji M., Bahadori S., Abdolmohammadi A. 2013. Effect of royal jelly in ovo injection on embryonic growth, hatchability, and gonadotropin levels of pullet breeder chicks. Theriogenology 80, 193-198, https://doi.org/10.1016/j.theriogenology.2013.04.013

Mountzouris K.C., Tsitrsikos P., Palamidi I., Arvaniti A., Mohnl M., Schatzmayr G., Fegeros K., 2010. Effect of probiotic inclusion levels in broiler nutrition on growth performance, nutrient digestibility, plasma immunoglobulins, and caecal microflora composition. Poult. Sci. 89, 58-67, https://doi.org/10.3382/ ps.2009-00308

Nichols A.W., 2007. Probiotics and athletic performance: A systematic review. Curr. Sports Med. Rep. 6, 269-273, https://doi. org/10.1007/s11932-007-0044-5
NRC (National Research Council), 1994. Nutrient Requirements of Poultry. $9^{\text {th }}$ Revised Edition. The National Academies Press. Washington, DC (USA), https://doi.org/10.17226/2114

Ohta Y., Kidd M.T., Ishibashi T., 2001. Embryo growth and amino acid concentration profiles of broiler breeder eggs, embryos, and chicks after in ovo administration of amino acids. Poult. Sci. 80, 1430-1436, https://doi.org/10.1093/ps/80.10.1430

Orsi R.O., Funari S.R.C., Soares A.M.V.C., Calvi S.A., Oliveira S.L., Sforcin J.M., Bankova V., 2000. Immunomodulatory action of propolis on macrophage activation. J. Venom. Anim. Toxins 6, 205-219, https://doi.org/10.1590/S010479302000000200006

Patterson J.A., Burkholder K.M., 2003. Application of prebiotics and probiotics in poultry production. Poult. Sci. 82, 627-631, https://doi.org/10.1093/ps/82.4.627

Pender C.M., Kim S., Potter T.D., Ritzi M.M., Young M., Dalloul R.A., 2016. Effects of in ovo supplementation of probiotics on performance and immunocompetence of broiler chicks to an Eimeria challenge. Benefic. Microb. 7, 699-705, https://doi. org/10.3920/BM2016.0080

Pruszynska-Oszmalek E., Kolodziejski P.A., Stadnicka K. et al., 2015. In ovo injection of prebiotics and synbiotics affects the digestive potency of the pancreas in growing chickens. Poult. Sci. 94, 1909-1916, https://doi.org/10.3382/ps/pev162

Prytzyk E., Dantas A.P., Salomao K., Pereira A.S., Bankova V.S., DeCastro S.L., Aquino Neto F.R., 2003. Flavonoids and trypanocidal activity of Bulgarian propolis. J. Ethnopharmacol. 88, 189-193, https://doi.org/10.1016/S0378-8741(03)00210-1

Quinn P.J., Carter M.E., Markey B.K., Carter G.R., 1992. Clinical Veterinary Microbiology. Wolfe Publishing. London (UK), pp. 61-65

Raheema R.H., 2016. Effect of pomegranate peel extract on some biochemical and histopathological parameters in experimental induced mice with Staphylococcus aureus. J. Anim. Health Prod. 4, 42-49, https://doi.org/10.14737/journal. jahp/2016/4.2.42.49

Salmanzadeh M., 2012. The effects of in-ovo injection of glucose on hatchability, hatching weight and subsequent performance of newly-hatched chicks. Rev. Bras. Cienc. Avic. 14, 137-140, https://doi.org/10.1590/S1516-635X2012000200008

Shafey T.M., Mahmoud A.H., Alsobayel A.A., Abouheif M.A., 2014. Effects of in ovo administration of amino acids on hatchability and performance of meat chickens. South Afr. J. Anim. Sci. 44, 123-130, https://doi.org/10.4314/sajas.v44i2.4

Sultan A., Ullah T., Khan S., Ullah Khan R., 2015. Effect of organic acid supplementation on the performance and ileal microflora of broiler during finishing period. Pak. J. Zool. 47, 635-639

Tannock G.W., Savage D.C., 1974. Influences of dietary and environmental stress on microbial populations in the murine gastrointestinal tract. Infect. Immunol. 9, 591-598

USDA (US Department of Agriculture), 2014. Nutrient data for honey. USDA National Nutrient Database for Standard Reference, Release 27. http://www.ars.usda.gov/ba/bhnrc/ndl

Vilà B., Fontgibell A., Badiola I., Esteve-Garcia E., Jiménez G., Castillo M., Brufau J., 2009. Reduction of Salmonella enterica var. Enteritidis colonization and invasion by Bacillus cereus var. toyoi inclusion in poultry feeds. Poult. Sci. 88, 975-979, https://doi. org/10.3382/ps.2008-00483

Yuan J., Liu J., Hu Y. et al., 2012. The immunological activity of propolis flavonoids liposome on the immune response against ND vaccine. Int. J. Biol. Macromol. 51, 400-405, https://doi. org/10.1016/j.jijbiomac.2012.06.002

Zhai W., Rowe D.E., Peebles E.D., 2011. Effects of commercial in ovo injection of carbohydrates on broiler embryogenesis. Poult. Sci. 90, 1295-1301, https://doi.org/10.3382/ps.2010-01130 